\title{
New Business Models in the Energy Sector
}

\author{
Maria Alejandra Caporale Madi \\ Department of Economic Theory, Institute of Economics, State University of Campinas, Campinas, Brazil
}

\section{Email address:}

alejandra_madi@yhaoo.com.br

\section{To cite this article:}

Maria Alejandra Caporale Madi. New Business Models in the Energy Sector. Science Journal of Energy Engineering.

Vol. 5, No. 3, 2017, pp. 63-67. doi: 10.11648/j.sjee.20170503.12

Received: June 30, 2017; Accepted: July 20, 2017; Published: October 23, 2017

\begin{abstract}
After the 1970s, the reorganization of the markets at the global level has been overwhelmed by the financial logic of investment in a setting characterized by expansion of institutional investors. Within this framework, the private equity funds' investment strategies turn out to focus on short-term profits. Besides, these funds have enhanced the expansion of new business models where the process of strategic disinvestment is part of the financial management. Considering this background, this paper addresses that the evolution of the current global business environment in the energy sector has been attached to the new financial and business dynamics where private-equity funds are relevant to apprehend the recent investment and disinvestment trends in renewables.
\end{abstract}

Keywords: Business Models, Energy Sector, Private Equity Funds, Renewables

\section{Introduction}

After the 1970s, the reorganization of the global markets has been overwhelmed by the financial logic of investment in a setting characterized by the expansion of institutional investors [1]. Within this scenario, investors have turned turn out to focus on short-term gains [2]. As recalled Hyman Minsky, in contemporary capitalism, finance determines the pace of investment since the corporations' strategic decisions have been increasingly subordinated to speculative financial commitments [3].

The evolution of the current global business environment in the energy sector has also been attached to the new financial dynamics where private-equity funds are new relevant institutional investors [4]. In spite of the potential relevance of the private equity investments, there is a limited understanding of their impact on energy conditions. Considering this background, this paper addresses that the evolution of the current global business environment in the energy sector has been attached to the new financial and business dynamics where private-equity funds are relevant to apprehend the recent investment and disinvestment trends in renewables.

\section{The Private Equity Business Model}

The term "private equity" encompasses financial techniques aimed to finance investment in companies that do not involve the use of public tradable assets [5]. The typical categories of private equity or "alternative investment" funds include: venture capital funds; leveraged buyout funds; hedge funds; fund-to-funds; and captive funds [6]. The share of private equity investments in the total volume of mergers and acquisitions exceeds $20 \%$ in some OECD economies [7]. The growth of the private equity firms has been quickly becoming global voracious acquirers of assets [8]. Indeed, private equity investments have not only defined new parameters to attractive investment decisions, but also fostered the credit and capital market's expansion.

What the private equity model has introduced is a high risk combination of leveraged debt financing with a short-term intent to resell the business in order to extract extraordinary returns [9]. The planning horizon is becoming shorter and the returns on investments are prioritized above real economic performance. The deep changes in the way investments is made, in how companies operate and in what kind of strategic planning is predominant in large parts of the business is intimately linked to the continuous growth of private equity and hedge funds - also called the new drivers of globalization [10].

In a private-equity funds' portfolio structure, a company acquisition is equivalent to an addition to a stock of financial assets [11]. Thus, the selection of the portfolio companies has been influenced by the potential market growth and profits, 
besides legal and incentive structures, among other factors. This investment is guided by expectations about short-run cash flows, mainly anticipated dividends and non-equity based fees.

It is worth noting that private equity investments, mainly buyouts, fundamentally differ from a traditional merger or acquisition in two important ways. First, the acquired company pays the cost of its own acquisition through debt and fees. Secondly, the private equity investor is necessarily aggressive in pursuit of such profits. These two elements are central to the leveraged buyout process and pose particular challenges to unions when engaging and bargaining collectively with private equity portfolio companies. Generally, the potentially adverse restructuring impacts of leveraged buyouts on workers tend to increase the higher the targeted return on investment, the more leveraged the deal, the faster the withdrawal of equity and the shorter the period before exiting the investment [12].

There are some stages in the consolidation of the private equity business model. In the first stage, a private equity firm creates a private equity fund and obtains commitments from investors (limited partners) to provide capital to its fund. Later, when the firm undertakes buyouts, it calls on the investors to provide the capital. In particular, private equity fund centralize endowments from public and corporate pension plans, foundations, insurance companies, and wealthy individuals in order to assume a key - role in investment buyouts. In the second stage, the private equity firm identifies potential companies for its fund to acquire. In the third stage, the private equity firm obtains a loan commitment, typically from commercial or investment banks, that it then uses to help finance its fund's acquisition of the target company. A loan commitment is a promise from the lender to make available in the future a specified amount of credit under specified terms and conditions. Loans are an essential component of an LBO (leveraged buyout) because private equity firms typically contribute through their funds only a fraction of the capital needed to complete the deal. In the fourth stage, after the buyout of the target company, the private equity firm seeks to increase the value of the company. Finally, in the fifth stage, the private equity fund sells the company at a profit and earns a return for its fund investors. Considering all these stages, the exit conditions become crucial in the investment decision-making process because capital mobility shortens the maturation of investments.

Under the private equity firms' governance, managers have privileged liquidity and high levels of debt to increase short-term profits. As the rationalization adjustment process is not implemented by the investors, the performance targets and debt repayment put pressure on the management organizational practices. After the takeover, the generation of cash flows - to pay fees, dividends and debts - require growing cost reductions with decisive effects on labour relations, employment trends, social benefits and unions' actions. Consequently, the reorganization of the production reshapes tasks and the control of workers in a context characterized by turnover, outsourcing and casual work. As the rationalization adjustment process is not implemented by the investors, the performance targets and debt repayment put pressure on the management organizational practices.

The private equity business model, as the main agent for recent mergers and acquisitions, has both evolved from and fed a broader process of increased financialization of corporate behaviour. While global financial assets grow at a fast speed, real investment and the share of wages in the national income do not follow the same trend [13]. Indeed, the private equity investments must be analyzed in a context of capitalist speculative finance where short-term value creation is the finality of investors. Although private equity strategies are anchored on the productive sphere but these strategies aim to preserve short-term liquidity in a speculative financial setting. Remembering Keynes's words:

Speculators may do no harm as bubbles on a steady stream of enterprise. But the position is serious when enterprise becomes the bubble on a whirlpool of speculation. When the capital development of a country becomes a by-product of the activities of a casino, the job is likely to be ill-done. The measure of success attained by Wall Street, regarded as an institution of which the proper social purpose is to direct new investment into the most profitable channels in terms of future yield, cannot be claimed as one of the outstanding triumphs of laissez-faire capitalism which is not surprising, if I am right in thinking that the best brains of Wall Street have been in fact directed towards a different object [14].

Considering Keynes' words, it can certainly be said that the private equity business model privileges the expansion of speculative bubbles both in the financial and in the real sector. Private equity managers are spreading, in truth, a business model where the target is to create short-term value and to sell the portfolio companies some years later in a process known as strategic disinvestment [15]. In truth, value creation in this business model involves social relations driven by profit and competition. As private equity investors' motive is not growth per se, but value extraction, the social losses in terms of unemployment, working conditions, workers' rights and income distribution has been relevant because short-termism has been "institutionalized at the workplace and in society" [16].

\section{Investment Trends in the Energy Sector}

The evolution of the current global business environment has been attached to the new financial dynamics where private-equity funds are new relevant institutional investors [17]. Private equity funds have grown from a small participation in the financial market in the early 1980s to an important driver of financial globalization today [18].

In a private-equity funds' portfolio structure, the company acquisition and its disinvestment process are both strategic financial decisions. Therefore, exit conditions become crucial in the investment decision-making process because capital 
mobility shortens the maturation of investments. Private equity funds typically hold an acquired company from up to 5 years before trying to realize their return. A private equity fund typically has a fixed life of 10 years, generally giving the private equity firm 5 years to invest the capital raised in its fund and 5 years to return the capital and expected profits to its fund investors.

Uncertainty about exit conditions could extend the holding period and put higher pressure on the levels of employment. In other words, the private equity business model, fund managers acting as entrepreneurs may feel more or less confident with regard to their exit conditions and, therefore, put pressure on employment conditions throughout the holding period. The consequences of the activist approach in management practices might be associated with the:

i. Substitution of workers through robotics;

ii. Utilization of telecom and information technology to foster remote services;

iii. Expansion of outsourcing and crowdsourcing;

iv. Strategies of cost reduction through layoffs, closures, outsourcing;

v. Reduction of the volume of productive and Research \& Development investments [19].

The 2008 global financial crisis brought new challenges to decisions about energy investments. After the crisis, the policy of quantitative easing shaped the evolution of private equity funds' performance, mainly the performance of bigfunds. Indeed, central banks' policy based on quantitative easing has been decisive to the expansion of liquidity. The new near-zero interest rate policy has been decisive to refinancing private equity borrowers, inflate asset valuations and influenced the investment and exit strategies of private equity funds [20]. Indeed, in the period 2009-2015, the private equity scenario presented the following features:

i. Low interest rates and low-cost debts;

ii. High levels of liquidity king to be invested or reinvested;

iii. Future expectations of higher performance than financial assets (sovereign bonds and fixed income) and real estate investments;

iv. Increasing fund-raising [21].

After the global crisis, in truth, the quantitative easing policy has been the key-driver that favoured investment in renewables by mainly reducing the debt costs for projects. For example, in 2016, many fund managers increased their investments in wind and solar projects. While Venture Capital firms especially are focusing on niche investments with bigger risks and smaller scales, private equity funds are orienting their investments to conventional renewable energy projects [22]. Considering this scenario, among some private equity fund managers' current strategies related to mitigation actions can highlight:

i. Focus on renewable energy investments: Fund managers are focusing on conventional investments that do not require $\mathrm{R} \& \mathrm{D}$ spending.

ii. Increasing fund-raising among pension funds. Fund managers have increased the financial endowments from pension funds to match liabilities with projects in clean power. For instance, Octopus Investments Ltd/ has invested in solar and wind projects.

iii. Global market diversification. Some fund managers are searching outside Europe for higher returns in Latin America, Asia and Africa. For example, Terra Firma Capital Partners Ltd. is considering to invest in energy projects in Vietnam, Saudi Arabia, Iran, Ghana and Uganda [23].

Taking into account this background, which might be the challenges for private equity investments in energy projects after 2016? So far, the main challenges seem to be:

i. In 2016, the actual interest rates paid by renewable energy project developers increased and, in addition, the interest policy rate might be augmented by central banks in the near future putting pressure on debt costs [24].

ii. Longer holding periods will be required to achieve the fund managers' expected returns.

iii. Recent concerns have arisen with matching the duration of liabilities and assets in the private equity funds' potfolios.

iv. And finally, legal, tax, regulatory and political changes might also dampen future profitability.

As mitigation actions under private equity funds have followed the principle of business profitability, these challenges might affect future profits and strategic investments in the energy sector. In this context, overwhelmed by the search for financial restructuring, cost adjustments and business efficiency, the private equity business model might threaten the long-term sustainability of clean energy investments. As long as clean energy investments are capital-intensive and involve long-run planning and operating decisions, any sustainable clean energy investment pattern requires long-term financial and investment commitment, political compromise, stability of market regulation, besides the enforceability of contracts and property rights.

Considering the current climate finance landscape, it is urgent to reassess the importance of public policies regarding further regulation not only relative to new strategic investments oriented to mitigation, but also to mergers and acquisitions led by private equity funds in the energy sector. It is also worth remembering that clean energy investments are cyclically affected by the evolution of macroeconomic policy and the evolution of cash flows. Consequently, clean energy investments that only respond to short-run market conditions will not favor the shift to a clean energy growth pattern.

\section{Conclusions}

Private equity funds are, in truth, mechanisms that promote new business models in the context of the expansion of the global financial markets. Taking into account this background, the cutting question related to the future of strategic investments at the local and global levels is, as 
Hyman Minsky warned, "Who will benefit?" [25].

In the current global scenario, scaling up climate finance and the alignment of this finance with climate change priorities in adaptation and mitigation projects is decisive to promote a green economy. In this attempt, investment and climate finance need to be thought as interconnected. Consequently, there is the need to enhance the articulation of the climate change issues with the dynamics of the global financial system.

On behalf of the importance of local and global sources of climate finance in adaption and mitigation actions, it is vital to get right national policies and institutions. Indeed, a broad set of issues are preventing the access to climate finance, such as: lack of technical capacity to develop projects; difficulties in following the requirements of private equity funds to access finance, political instability, among others. As a matter of fact, climate actions at the local level should follow some guiding principles:

i. Commitment to face global warming;

ii. Maintenance of a long term and a short term investment perspective;

iii. Proactive options (mitigation) must be combined with plans to live with the consequences of global warming (adaptation);

iv. There is the need to implement a combine set of actions that include mitigation and adaptation measures;

v. Public and private resources should address climate finance challenges;

vi. Allocation of resources must support human rights such as food security and gender equality.

Recalling John Maynard Keynes's analysis about the failures of the free markets in fostering stable levels of spending and employment, those investments required to promote the shift to a low carbon economy cannot be left to the free markets [26]. Indeed, climate finance cannot be left to the free markets.

\section{References}

[1] Crotty, J. (2002) The effects of increased product market competition and changes in financial markets on the performance of nonfinancial corporations in the neoliberal era'. Working Paper Series, 44. Political Economy Research Institute, University of Massachusetts Amherst.

[2] Lazonick, W. and O'Sullivan, M. (2000) "Maximizing shareholder value: a new ideology for corporate governance", Economy and Society, 29 (1).

[3] Minsky, H. P. (1986) Stabilizing an unstable economy. New Haven: Yale University Press.

[4] Gonçalves, J. R. B. and Madi, M. A. C. (2011) Private equity investment and labor: faceless capital and the challenges to trade unions in Brazil. In: M. Serrano, E. Xhafa and M. Fichter (Eds.) (2011) Trade unions and the global crisis: Labour's visions, strategies and responses. Geneve: Intenational Labour Office.
[5] Hickey, J. et al. (2007) Private Equity. Business Information Alert, 19 (3); Metrick, A. and Yasuda, A. (2007) The Economics of Private Equity Funds, Wharton School: University of Pennsylvania.

[6] Appelbaum, E. and Batt, R. (2014) Private Equity at Work: When Wall Street Manages Main Street, United States: Russell Sage Foundation.

[7] Tate, A. (2007) The Effect of Private Equity Takeovers on Corporate Social Responsibility. International Officer, Australian Council of Trade Unions. Retrieved from http://www.accsr.com.au/pdf/pet_speech_Alison_Tate.pdf; TUAC (2008). Pension Fund Investment in Private Equity. Report. Paris.

[8] Dixon, H.; Cox, R. and Chancellor, E. (2007) "Conglomerate Comparisons - Will Private Equity Empires Parallel Predecessors of 1960s and Fall Out of Fashion Too?", Wall St. Journal, January 2, p. C12.

[9] Klier, D.; Welge, M and Harrigan, K. (2009) The Changing Face of Private Equity: How Modern Private Equity Firms Manage Investment Portfolios. Journal of Private Equity, 12 (4), Fall.

[10] ITUC- CSI (2007) Labour and the Shifting Power Equation: Statement of Labour Leaders to the World Economic Forum Annual Meeting Davos, 24-28, January. Retrieved from http://www.ituc-csi.org/IMG/pdf/WEF_Statement__Labour_and_the_Shifting_Power_Equation_-_Rev_EN.pdf

[11] Cullen, A. and James, S. (2007) Private equity and Business Information. Part 3: Business Information Services and Private equity: North American Involvement. Business Information Alert. Nov/Dec, 19 (10), pp. 1-4.

[12] International Union of Food, Agricultural, Hotel, Restaurant, Catering, Tobacco and Allied Workers' Association -IUF (2007) A Workers' Guide to private Equity Buyouts. Geneve and IUF (2008) Private Equity Buyouts: A Trade Union View. Brussels.

[13] International Union of Food, Agricultural, Hotel, Restaurant, Catering, Tobacco and Allied Workers' Association -IUF (2007) A Workers' Guide to private Equity Buyouts. Geneve.

[14] Keynes, J. M. [1936 (1964)] The General Theory of Employment, Interest, and Money. New York: Harcourt Brace. Chapter 12, section VI.

[15] Wheatley, J. (2010). Capital markets: Private equity funds explore the market. Retrieved from

http://www.ft.com/cms/s/0/cbfe7ce6-571c-11df-aaff0144feab49a.html\#axzzlezwgqbFE

[16] International Union of Food, Agricultural, Hotel, Restaurant, Catering, Tobacco and Allied Workers' Association -IUF (2007) A Workers' Guide to private Equity Buyouts. Geneve. p. 24.

[17] Celik, S. and Isaksson, M. (2013) "Institutional Investors as Owners: Who Are They and What Do They Do?", OECD Corporate Governance Working Papers, 11, France: OECD Publishing. Retrieved from http://dx.doi.org/10.1787/5k3v1dvmfk42-en

[18] Tannon, J. M. and Johnson, R. (2005) "Transatlantic Private Equity: Beyond a Trillion Dollar Force”, Journal of Private Equity, 8 (3), pp. 77-80. 
[19] Cressy, R.; Munari, F. and Malipiero, A. (2007) Creative destruction? UK Evidence that buyouts cut jobs to raise returns. Working Paper Series. Retrieved from http://ssrn.com/abstract=1030830; Aldatmaz, S. and Brown, G. W. (2013) "Does Private Equity Hurt or Help the Economy?", Research Paper, Private equity research Consortium, Kenan-Flagler Business School, The University of North Carolina at Chapel Hill.

[20] Bain \& Company (2015) Global Private Equity Report 2015. U.S.A: Bain \& Company, Inc. p. 2; Prequin (2015) Prequin Private Equity \& Venture Capital Report. Retrieved from https://www.preqin.com/docs/reports/2015-Preqin-GlobalPrivate-Equity-and-Venture-Capital-Report-Sample-Pages.pdf

[21] Makovich, L. (2012). Putting Energy Back to Work. Retrieved from http://www3.weforum.org/docs/WEF_EN_EnergyEconomicG rowth_IndustryAgenda_2012.pdf; Chevalier. J. Energy and the Economy in Europe (2012) Retrieved from http://www3.weforum.org/docs/WEF_EN_EnergyEconomicG rowth_IndustryAgenda_2012.pdf; IEA (2015) World Energy Outlook. Retrieved from

http://www.iea.org/publications/freepublications/publication/ WEO2015SpecialReportonEnergyandClimateChange.pdf; Bain \& Company (2015) Global Private Equity Report 2015. U.S.A: Bain \&Company, Inc.

[22] Bloomberg New Energy Finance (2017) Green technologies get boost from EU's venture capital funds. Retrieved from https://about.bnef.com/blog/green-technologies-get-boostfrom-eus-venture-capital-funds/

[23] On global mitigation and adaption investment trends also see UNFCC (2016a) UNFCCC Standing Committee on Finance 2016. Biennial Assessment and Overview of Climate Finance Flows Report. Retrieved from $\mathrm{http}: / /$ unfecc.int/files/cooperation_and_support/financial_mec hanism/standing committee/application/pdf/2016 ba technic al_report.pdf

[24] Mc Crone, A. (2016) If interest rates turn, clean energy will find it tougher. Bloomberg New Energy Finance. Retrieved from https://about.bnef.com/blog/mccrone-interest-rates-turnclean-energy-will-find-tougher/

[25] Minsky, H. P. (1986) Stabilizing an unstable economy. New Haven: Yale University Press.

[26] Keynes, J. M. [1936 (1964)] The General Theory of Employment, Interest, and Money. New York: Harcourt Brace.

\section{Biography}

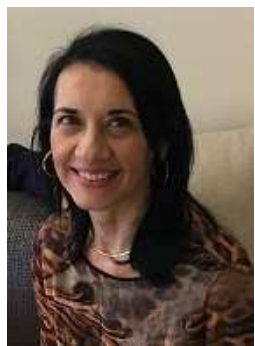

Maria Alejandra Caporale Madi holds a $\mathrm{PhD}$ in Economics. Her academic career includes a long-term professorship at UNICAMP (Brazil), besides visiting professorships at the Universities of Manitoba and Kassel, in addition to a position as Avocational Lecturer at Steinbes University Berlin. She co-edited some of The Green Economics Institute books, including The Greening of Global Finance. She also co-edited the World Economics Association books Ideas towards a new international financial architecture? and Capital and Justice. Her latest books include Global Finance and Development; Small Business in Brazil and Pluralist Reading in Economics: Key-concepts and policy-tools for the $21^{\text {st }}$ century. 